JAKUB BORNIO

Uniwersytet Wrocławski

ORCID: 0000-0001-7906-7475

jakub.bornio@uwr.edu.pl

\title{
Rozmowa Jakuba Bornio z Ekaterine Tkeszelaszwili,
}

byłą sekretarz Rady Bezpieczeństwa Narodowego i minister spraw zagranicznych Gruzji w okresie wojny z Rosją w 2008 r.

\section{An interview by Jakub Bornio with Ekaterine Tkeszelashvili,}

former secretary of the National Security Council and Minister of Foreign Affairs of Georgia during the war with Russia in 2008 


\section{Ekaterine Tkeszelaszwili}

gruzińska prawniczka, specjalistka ds. stosunków międzynarodowych i polityk, m. in. była minister sprawiedliwości, sekretarz Rady Bezpieczeństwa Narodowego, prokurator generalna, a także minister spraw zagranicznych Gruzji od 5 maja do 5 grudnia $2008 \mathrm{r}$. 
Proszę pozwolić, że rozpocznę od szczytu NATO w Bukareszcie, gdzie odrzucono postulat objęcia Gruzji i Ukrainy planem działania na rzecz członkostwa ${ }^{1}$, ale jednocześnie obiecano im bliżej nieokreśloną perspektywę akcesji. Jak interpretuje Pani te wydarzenia - jako porażkę czy sukces?

Bukareszt był momentem kulminacyjnym. Podjęto tam trudne decyzje i musimy się im przyglądać z wielu perspektyw. Szczególnie istotne były dwa aspekty. Po pierwsze, specyfika czasu, ponieważ był to pierwszy raz, kiedy rząd USA naprawdę forsował objęcie Gruzji i Ukrainy planem członkostwa. Jego stanowisko oddziaływało na innych członków sojuszu, stymulując i wzmacniając wsparcie z ich strony, ale też nie wszystkich, niektóre państwa obawiały się bowiem pogorszenia relacji z Rosją. Można przypuszczać, że na ostateczny wynik całej sprawy wpłynął fakt, że kadencja ówczesnej amerykańskiej administracji dobiegała końca. Po drugie, bukaresztańska decyzja uplasowała Gruzję i Ukrainę na twardej drodze do członkostwa. Niektórzy argumentowali, że było to coś więcej, niż mogło zaǵwarantować objęcie tych państw programem MAP, ponieważ potwierdzone zostało ich przyszłe członkostwo. Niemniej jednak sama decyzja, a nawet bardziej poprzedzająca ja dyskusja, była sygnałem, że sojusz nie jest gotów do zaciągania zobowiązań względem Gruzji i Ukrainy, właśnie ze względu na obawy o pogorszenie relacji z Rosją.

\section{A zatem Stany Zjednoczone były dla Gruzji głównym punktem odniesienia?}

Należy podkreślić, że w tamtym okresie Gruzja prowadziła bardzo aktywną działalność dyplomatyczną na kierunku sojuszniczym. Przeprowadziliśmy udane negocjacje bilateralne z USA, a równocześnie stale i aktywnie rozmawialiśmy ze wszystkimi członkami sojuszu. Nie traktowaliśmy Stanów Zjednoczonych jako lidera, który mógłby podjąć decyzję w imieniu całego NATO. Nigdy nie mieliśmy takiej percepcji. Zdawaliśmy sobie sprawę, które państwa były przeciwne objęciu Gruzji planem członkostwa. Ich stanowisko wiązało się raczej z obecnością Rosji w gruzińskich regionach Osetii Południowej i Abchazji, a nie z uwarunkowaniami wewnętrznymi czy postępami Gruzji w realizacji wymogów członkowskich. 


\section{Jak szczyt w Bukareszcie miał się do późniejszych działań Rosji?}

Postrzegamy go jako moment zwrotny w kwestii całkowitego odkrycia przez Rosję swoich kart i ujawnienia roszczeń co do wpływów w regionie. Posunęła się ona nawet do werbalnego ataku, całkiem otwarcie kwestionując państwowość Ukrainy per se. Dla nikogo nie było wówczas tajemnicą, że sprzeciwiała się objęciu Gruzji planem członkostwa. Nasza ocena szczytu była niestety zbieżna z wydarzeniami, które nastąpiły tuż po nim. Rosja odczytała tę decyzję jako sygnał, że NATO nie jest jeszcze gotowe, by zaciągać jakiekolwiek zobowiązania w zakresie bezpieczeństwa i przyszłości Gruzji oraz Ukrainy, ale taki moment może nadejść. Obietnica została złożona, a zatem istniała taka możliwość. Władze na Kremlu wykorzystały to okienko możliwości i zareagowały na słabość, a może lepiej byłoby powiedzieć: brak zdolności Zachodu do stanowczego odrzucenia rosyjskich roszczeń odnośnie do swojej strefy wpływów. Moskwa odczytała ten sygnał i zareagowała. Wszyscy wiemy, co nastąpiło później: wojna w Gruzji w 2008 r., a następnie agresja na Ukrainę w 2014. Wojna z Gruzją dała Rosjanom sygnał, że nawet przekroczenie czerwonych linii i pogwałcenie suwerenności państwa oraz jego granic nie niesie żadnych konsekwencji. W 2008 r. Rosja dokonała tego po raz pierwszy w sposób otwarty, a kilka lat później powtórzyła to wobec Ukrainy.

Mówiąc krótko, rezultaty szczytu w Bukareszcie były dwojakie. Z jednej strony zapewniał o przyszłym członkostwie Gruzji i Ukrainy w NATO, choć kwestią otwartą pozostawało, jak i kiedy ma to nastąpić. Z drugiej strony, Rosja dostała bardzo jasny sygnał: na ten moment nie ma zobowiązań $w$ zakresie bezpieczeństwa tych państw wobec jej roszczeń, ale mogą się pojawić. Dlatego władze w Moskwie musiały działać zdecydowanie i szybko, aby udaremnić jakiekolwiek perspektywy członkostwa Gruzji w NATO i zapewnić sobie wyłączą strefę wpływów w regionie.

Chce Pani zatem powiedzieć, że gdyby zadecydowano wtedy o objęciu Gruzji planem członkostwa, Rosja zachowałaby się inaczej?

Jestem o tym przekonana. Przyznanie Gruzji MAP byłoby dla Kremla sygnałem, że sojusznicy podjęli decyzję i doszli do konsensusu, że bezpieczeństwo Gruzji i Ukrainy ma na tyle istotnie znaczenie dla bezpieczeństwa NATO, że należy wytyczyć obu krajom jasną ścieżkę do członkostwa. Jestem przekonana, że klarowne zobowiązania w zakresie ich bezpieczeństwa, sygnalizujące determinację sojuszu, aby nie akceptować rosyjskich 
roszczeń dotyczących wyłącznej strefy wpływów w sąsiedztwie, zmieniłyby kalkulacje Moskwy. Muszę tu wyraźnie zaznaczyć, że decyzja w sprawie MAP nie byłaby tożsama z gotowością do wysłania sił NATO na wojnę z Rosją w obronie państwa niebędącego członkiem sojuszu, ale stanowiłaby silny sygnał, że agresja spotka się z konsekwencjami. Sam MAP, jako klarowna ścieżka do członkostwa umożliwiłby zaś Gruzji solidną modernizację zdolności obronnych i natychmiast utworzyłby ramy dla zdynamizowanej współpracy. Rozumiem, że trudno mieć pewność co by się wydarzyło, jednak widzieliśmy, że wahanie NATO co do objęcia Gruzji i Ukrainy planem członkostwa raczej sprowokowało niż zniechęciło Rosję do działań rewizjonistycznych.

Minister Radosław Sikorski ujawnił w swojej niedawno wydanej książce kulisy tego szczytu. Napisał, że największym przeciwnikiem objęcia Gruzji i Ukrainy planem członkostwa były Niemcy i że jest przekonany, że jeszcze przed szczytem obiecały one Rosji nieprzyznawanie MAP tym państwom. Jak Pani myśli, dlaczego Berlin był tak stanowczy, jeśli chodzi o współpracę Tbilisi i Kijowa z NATO?

Nie mam dowodów ani informacji o złożeniu Rosji takiej obietnicy, ale wcale by mnie to nie zdziwiło. Nie jest tajemnicą, że Niemcy były największym przeciwnikiem, być może nawet jedynym naprawdę liczącym się przeciwnikiem pozytywnej decyzji w sprawie MAP. Francja mogła się zgodzić, gdyby tylko zgodziły się Niemcy, ale tak się nie stało. Nie chcę spekulować na temat różnych wymiarów niemieckiego podejścia, ale jak widzimy teraz na przykładzie Nord Stream 2, jest to odzwierciedlenie strategicznej krótkowzroczności tego kraju wobec Rosji. Wbrew silnym i donośnym głosom z Europy i świata Niemcy prowadzą politykę wobec Rosji w oparciu o interesy biznesowe, a nie wspólne interesy strategiczne Europy i wspólnoty transatlantyckiej. Najgorszym wytłumaczeniem ich stanowiska byłoby to, że niektórzy wciąż patrzą na kraje Europy Wschodniej przez rosyjskie imperialne soczewki, akceptując - jeśli nie otwarcie, to milcząco - roszczenia Moskwy względem regiionu i nadal określając go mianem rosyjskiego podwórka.

Powiedziała Pani, że USA były jednym z największych zwolenników współpracy NATO z Gruzją. W tamtym okresie Wasza współpraca wojskowa była niezwykle intensywna, obejmując wspólne 
manewry, rozlokowanie w Gruzji amerykańskich sił i inne działania. Czy miało to jakiś wpływ na Waszą samoocenę i postrzeganie swojej roli w systemie międzynarodowym? Czy podnosiło to Waszą pewność siebie?

Cóż, jeśli chodzi o naszą współpracę z NATO - nie tylko z USA - to przez lata bardzo mocno się rozwijała. Do tamtego momentu uczestniczyliśmy we wspólnych operacjach w Iraku, a potem w Afganistanie. Gruzińskie oddziały stanowiły w Afganistanie najliczniejszy kontyngent z państw niebędących członkami sojuszu. Nasi żołnierze bez żadnych zastrzeżeń brali udział $\mathrm{w}$ operacji na najbardziej niebezpiecznych obszarach, takich jak Helmand. Nie jest więc tak, że nasza współpraca była doraźna i opierała się tylko na manewrach wojskowych. Były to systemowe działania w kontekście rozwoju naszych sił zbrojnych zgodnie ze standardami NATO i zapewnienia ich interoperacyjności. Powiedziałabym, że mieściło się to w spójnych usystematyzowanych ramach współpracy wojskowej.

Taka wyraźna prozachodnia orientacja Gruzji kolidowała oczywiście z rosyjskimi interesami. Na krótko przed wojną Rosja podejmowała działania, które musiały Was zaniepokoić. Manewry wojskowe, rozbudowa infrastruktury logistycznej czy rozmieszczanie dodatkowych sił $\mathrm{w}$ ramach misji pokojowej to tylko niektóre $\mathrm{z}$ nich. Jak interpretowaliście te posunięcia?

Cóż, były to systemowe zmiany zgodne z jasną strategią Rosji. Tamtejsze władze nigdy nie działają pochopnie, w sposób nieprzygotowany i spontaniczny. Najpierw kalkulują, badają grunt, analizują wyniki i dopiero do nich dostosowują swoje ruchy. Zanim zdecydują się na przekroczenie czerwonej linii, przecinają szereg różowych. Prowadzą uporczywą ofensywę drobnych faktów dokonanych, w większości na granicy prawa międzynarodowego, wykorzystując pojawiające się możliwości do potęgowania słabości i podatności swoich przeciwników. Operacje wielkoskalowe, jak w 2008 i 2014 r., nigdy nie biorą się znikąd, a drogę do decydującej ofensywy zawsze torują systematyczne działania podejmowane wcześniej. Ze swojej strony dokumentowaliśmy i analizowaliśmy posunięcia Rosji sprzed wojny. Byliśmy bardzo proaktywni i transparentni $\mathrm{w}$ dzieleniu się tymi informacjami z naszymi partnerami i społecznością międzynarodową. Nie wspominając o wcześniejszych okresach, a skupiając się jedynie na pierwszej fazie wielkoskalowej operacji, mogę powiedzieć, że nie było sytuacji, w której działania 
Rosji zostałyby nieodnotowane. Problem w tym, że nigdy nie zaproponowano rozwiązania, które mogłoby powstrzymać tę ofensywę, a przecież nie zaczęła się nağle 7 czy 8 sierpnia, ale postępowała od dłuższego czasu.

Pierwszym krokiem było legitymizowanie przez Federację Rosyjską aktów prawnych wydawanych przez lokalne separatystyczne władze, co de iure stanowiło naruszenie suwerenności Gruzji. Zostało to poprzedzone czasowym zwiększeniem $\mathrm{w}$ regionie liczebności wojsk działających pod szyldem sił bezpieczeństwa. Jeśli dobrze pamiętam, w momencie szczytowym w maju Rosja weszła do Abchazji z liczącymi 1,5-2 tys. ludzi oddziałami paramilitarnymi, których nie można było nazwać siłami pokojowymi. Istniały bowiem w tym zakresie wyraźne ograniczenia, a dla sił pokojowych operujących w regionie Abchazji przewidziano status podobny do niebieskich hełmów. Wojska wysłane przez Rosję nie mieściły się w tych ramach, dlatego żądaliśmy ich usunięcia, ale władze w Moskwie ignorowały nasze apele. $\mathrm{W}$ obliczu wielu prowokacji w terenie mogliśmy tylko komunikować naszym partnerom, że nie jesteśmy w stanie dłużej akceptować rosyjskiej obecności, ponieważ jej charakter wykraczał daleko poza margines nawet szeroko rozumianych sił pokojowych. Operacja podlegała rozdziałowi 6 Karty Narodów Zjednoczonych, więc aby była zgodna z prawem, wymagała akceptacji państwa przyjmującego. Kierujące rokowaniami w sprawie abchaskiego konfliktu sekretarz generalny ONZ i Grupa Przyjaciół Gruzji poprosili nas o cierpliwość, by mogli zaproponować $w$ formacie negocjacji zmiany łagodzące i tak już bardzo wyeskalowaną sytuację i umożliwiające odmrożenie rozmów. Zgodziliśmy się na to i nie cofnęliśmy zgody na obecność sił pokojowych. Rosja kontynuowała tymczasem przebudowę i modernizację połączenia kolejowego z wybrzeża do aktualnej linii rozgraniczenia między regionem Abchazji a resztą Gruzją. Zarówno w czasie wojny, jak i w poprzedzających ją miesiącach aktywnie wykorzystywano to połączenie do transportowania w głąb lądu czołgów i ciężkiej amunicji wyładowywanych z okrętów cumujących na wybrzeżu. Sprzęt ten użyty został później, gdy Rosjanie parli naprzód, wkroczyli do Zuǵdidi, a następnie odcięli zachodnią część Gruzji od reszty kraju. Kiedy więc my czekaliśmy, aż nasi partnerzy zaproponują plan negocjacyjny, Rosjanie kontynuowali przygotowania do operacji wojskowej. Wypracowany ostatecznie plan Steinmeiera nie był dla nas idealny, zawierał bowiem kilka niepokojących elementów. Ponieważ jednak bardzo zależało nam na deeskalacji i niedopuszczeniu do działań wojskowych, zaakceptowaliśmy go i zdecydowaliśmy, 
że będziemy kontynuować rozmowy z Rosjanami. Następnie Frank Walter Steinmeier udał się do Rosji, ale tamtejsze władze zwlekały z odpowiedzią, a ostatecznie nie zgodziły się przyjechać do Berlina na negocjacje mające się odbyć na początku sierpnia, tłumacząc to brakiem czasu z powodu planów wakacyjnych. Był to bardzo wyraźny sygnał, że nie zamierzali podejmować żadnych rokowań i byli gotowi do wzniesienia muru.

\section{Co wydarzyło się na krótko przed operacją i jaka była Wasza poli-} tyka w dniach poprzedzających wojnę?

Operacje poprzedziło zwiększenie liczby i skali prowokacji w regionie Osetii Południowej, gdzie nie istniało wyraźne rozgraniczenie między terytoriami kontrolowanymi przez nas i władze wspierane przez Rosję. Wyglądało to jak pola na szachownicy: wioski, które kontrolowaliśmy my, były całkowicie otoczone i zamknięte przez bombardowanie z ich strony, które nasiliło się w lipcu, a jeszcze bardziej w sierpniu. Zawsze odpowiednio rejestrowaliśmy te incydenty i zołłaszaliśmy je misji OBWE. Organizowaliśmy też liczne wyjazdy zagranicznych obserwatorów w rejon konfliktu, aby mogli zobaczyć skutki bombardowań i ostrzałów. Publikowaliśmy wreszcie oświadczenia dyplomatyczne, że obie strony powinny dążyć do deeskalacji. Tymczasem Rosji wciąż nie spotykały żadne realne konsekwencje. Największym błędem było to, że nigdy nie zakomunikowano jej w jasny sposób, jakie byłyby konsekwencje naruszenia czerwonych linii. Do tego czasu przekroczyła już szereg linii różowych, testowała grunt i nigdy nie wyciągnięto wobec niej z tego powodu żadnych konsekwencji. Ostatecznie w 2008 r. Rosjanie zdali sobie sprawę, że muszą wykorzystać okienko możliwości, które pojawiło się przy zmianie władzy w USA, zanim Gruzja zdołała się umocnić jako państwo, a NATO skonsolidowało się we wsparciu dla jej członkostwa. Władze na Kremlu zrealizowały swoje założenia, a społeczność Zachodu nie zdołała, niestety, im w tym przeszkodzić.

\section{Czy spodziewała się Pani, że Rosjanie podejmą działania ofen-} sywne przeciwko Gruzji na tak dużą skalę?

Od zawsze spodziewaliśmy się, a nawet wiedzieliśmy, że Rosja nie pozwoli nam się oswobodzić. To było oczywiste. Moskwa nieustannie ingerowała w naszą politykę wewnętrzną, gdy budowaliśmy demokrację. Zdawaliśmy sobie sprawę, jak mocno eskaluje sytuacja w terenie. Nieustannie próbowaliśmy ją załagodzić, nawet poprzez bezpośrednie negocjacje z Rosjanami, 
o czym często się zapomina, jakbyśmy nigdy tego nie próbowali. Po wyborze Dmitrija Miedwiediewa na urząd prezydenta od razu zorganizowaliśmy spotkania i przedstawiliśmy propozycje zmiany platformy negocjacyjnej, choć było to dla nas bardzo ryzykowne politycznie ze względu na model, który proponowaliśmy. Zakładał on, że międzynarodowe siły, w skład których wchodziliby również Rosjanie, wejdą tylko na pewien obszar Abchazji, a powyżej Suchumi wciąż obowiązywałby poprzedni układ. Chodziło nam o stopniową deeskalację i normalizację stosunków społecznych w terenie. Rosjanie jednak nie chcieli zaakceptować żadnych rozwiązań i stało się oczywiste, że nie zamierzają nawet udawać, że prowadzą negocjacje. Od zawsze obawialiśmy się i podejrzewaliśmy, że Rosja mogłaby się posunąć do ekstremum, ale nawet nam bardzo trudno było uwierzyć, że naprawdę rozpocznie prawdziwą wojnę, dopóki nie zobaczyliśmy, ile wojska zostało rozmieszczone przy granicy Gruzji w ramach ćwiczeń Kaukaz, i dopóki nie zorientowaliśmy się, że nigdy nie zostało ono wycofane. Następnie pod koniec lipca i na początku sierpnia byliśmy świadkami nieustannego ostrzału gruzińskich wiosek i wreszcie Tunel Rokijski wypełnił się nadjeżdżającymi rosyjskimi czołgami. Inwazja rozpoczęła się więc jeszcze przed 8 sierpnia, a misja rozpoznawcza, którą kierowała Heidi Tagliavini, bardzo wyraźnie wskazywała w raporcie rocznym, że jednostki regularnej armii rosyjskiej znajdowały się na terenie Gruzji wcześniej.

\section{Zapytałem, czy spodziewaliście się rosyjskiego zaangażowania} na tak wielką skalę, ponieważ staram się zrozumieć sens Waszych kolejnych działań.

Przed tymi wydarzeniami i po rozpoczęciu rosyjskich ostrzałów ogłosiliśmy jednostronne zawieszenie broni. Rosjanie zaczęli następnie wycofywać własnych cywilów, przygotowując się do operacji wojskowej. Jeżeli ma Pan wrażenie, że nic się nie działo, a następnie my podjęliśmy działania, które spowodowały wkroczenie Rosji, to nie jest to poprawne odzwierciedlenie faktów. Gdy wycofaliśmy się z unilateralnego zawieszenia broni i poczyniliśmy defensywne kroki mające na celu obronę naszych obywateli, wojna już trwała. Działania Rosjan postępowały, a ich jednostki masowo przechodziły przez Tunel Rokijski. To był moment, w którym porzuciliśmy nadzieję. Trzymaliśmy się jej do końca, a kiedy ogłosiliśmy zawieszenie broni, spotkała nas w kraju ostra krytyka polityczna, ponieważ ludzie wiedzieli, że we wsiach ostrzeliwani są cywile. W dwóch wioskach - Nuli 
i Awnewi - zniszczone zostały prawie wszystkie budynki mieszkalne. Otoczona ludność nie mogła się wydostać z miejsc zamieszkania i groziła jej rzeź. Ogłosiliśmy tę deklarację o zawieszeniu broni jako ostateczny gest dobrej woli, a nie porozumienie. Był to sygnał, że nie chcemy iść na wojnę, że wycofujemy wojska, utrzymujemy pozycje i nie odpowiadamy ogniem. Gruzińska opinia publiczna nie przyjęła tego dobrze, ponieważ wiedziała, że nasi cywile są ostrzeliwani, ale zrobiliśmy to, rozumiejąc, że jeżeli istnieje jakakolwiek szansa, aby jeszcze raz pokazać, że nie chcemy iść na wojnę, to był to ostatni moment. Przychodzi jednak punkt kulminacyjny, w którym nie możesz porzucić własnych ludzi i musisz rozpocząć operację defensywną.

\section{Czy podejmowaliście jakieś próby otwarcia kanału komunikacji} z Moskwą?

Ciągle.

\section{I jaka była reakcja strony rosyjskiej?}

Rosyjskie MSz było całkowicie zamknięte. Przydzieliliśmy to zadanie jednemu z naszych wiceministrów spraw zagranicznych, ponieważ ja działałam na innych frontach. Wszystkie próby zainicjowania rozmów na poziomie prezydentów, ministrów czy wiceministrów były daremne. Na kilka dni przed rozpoczęciem głównej fazy wojny podjęliśmy ostatnią próbę zorganizowania misji w terenie, $w$ Cchinwali. Mieli się tam spotkać przedstawiciel rosyjskiego ministerstwa, obserwatorzy i gruziński minister ds. reintegracji okupowanych regionów Temur Jakobaszwili, nasz główny negocjator w sprawach pojednania. Gdy rosyjska delegacja jechała do Cchinwali, dziwnym trafem pękła opona w samochodzie z konwoju, więc nie zdołała dotrzeć na miejsce. Rosjanie wycofywali się z wielu prób negocjacji, a ich dyplomacja była przez pewien czas zupełnie nieobecna.

Czy kiedy wybuchła wojna, prosiliście o jakąkolwiek pomoc zewnętrzną, włącznie z pomocą wojskową od partnerów z NATO?

Nigdy nie prosiliśmy i nie zamierzaliśmy prosić o żadną pomoc wojskową, wiedząc, że byłyby to daremne próby i nie moglibyśmy na nią liczyć. Zresztą nigdy tego nie oczekiwaliśmy. Jedyne, o co poprosiliśmy po rozpoczęciu wojny, to przyspieszone zezwolenie na powrót naszych oddziałów z Iraku o powrót do domu 2,5 tys. naszych najlepszych żołnierzy. I oni przybyli, ale 
wojna prawie dobiegała już końca. W tamtym trudnym czasie nie mogliśmy więc liczyć nawet na naszą najlepszą dywizję.

Czy w kręgach decyzyjnych Gruzji panowała zgoda odnośnie do sposobu reakcji na rosyjską ofensywę? Czy był ktoś, kto sprzeciwiał się kontroperacji wojskowej?

To byłby absurd, tak jak powiedziałam. W momencie rozpoczęcia akcji zbrojnej nie mogliśmy się nie bronić. Rosyjskie wojska znajdowały się już w obu regionach - Abchazji i Osetii Południowej. Jedyne, co mogliśmy zrobić, to zyskać na czasie, aby nie opanowały całego kraju i aby dyplomacja miała szansę na zawarcie jakiegoś porozumienia o zawieszeniu broni. Zadaniem naszych wojskowych było utrzymanie państwowości Gruzji i dokonali tego.

Jak zachowywała się $w$ tamtym czasie opozycja? Czy pamięta Pani próby wykorzystania tej sytuacji przez którąkolwiek ze stron w celu zwiększenia swojego poparcia społecznego lub zmniejszenia Waszego?

Nie przypominam sobie niczego takiego. W Gruzji istnieją pewne siły prorosyjskie, ale $\mathrm{w}$ tamtym czasie były one marginalne. Bardziej interesujące jest to, co wydarzyło się później, a mianowicie jak Rosja promowała narrację, wedle której daremne jest prowadzenie wobec Rosji suwerennej polityki. Głoszą to teraz obecny rząd Gruzji i będący udziałowcem Gazpromu oligarcha Bidzina Iwaniszwili. Taka narracja pojawiła się jednak znacznie później.

Czy próbowaliście zaangażować inne państwa regionu $\mathrm{w}$ rozwiązanie konfliktu?

Gdy jesteś w konflikcie z Rosją, bardzo trudno oczekiwać od sąsiadów, aby dzielili z tobą ten ciężar i partycypowali w rozwiązaniu konfliktu, zwłaszcza w momencie, gdy Armenia i Azerbejdżan toczą między sobą własny. Stale jednak wchodziliśmy z nimi w interakcje na różnych poziomach strategicznych. Jak Pan dobrze wie, Gruzja ma bardzo dobre, partnerskie stosunki strategiczne z każdym sąsiadem poza Rosją. Oczywiście byliśmy w kontakcie, dzieliliśmy się informacjami i poszukiwaliśmy rozwiązań regionalnych, ale bardzo trudno było oczekiwać, żeby te państwa mogły się przyczynić do rozwiązania konfliktu. 
Powiedziała Pani o roli Niemiec, wspominając rozmowy pokojowe Steinmeiera, które miały się odbyć w Berlinie. Wciąż nie porozmawialiśmy jednak o roli, jaką odegrała Francja, a wkład prezydenta Nicolasa Sarkozy'ego był niezwykle istotny.

Doprecyzujmy, że fakt nazwania planu nazwiskiem niemieckiego ministra spraw zagranicznych nie oznacza, że był to plan niemiecki. To była inicjatywa całej Grupy Przyjaciół Gruzji w ONZ. Francuzi pojawili się w kontekście innego rozwiązania.

Czy mieliście jakikolwiek wpływ na Sarkozy'ego i jego stanowisko podczas misji w Moskwie? Próbowaliście osiągnąć swoje cele wobec Rosji za pośrednictwem Sarkozy'ego?

Jeśli chodzi o misję prezydenta Francji, to pojawiła się ona w momencie krytycznym, gdy zadawaliśmy sobie pytanie, czy w ogóle uda nam się utrzymać państwowość Gruzji. Wojska rosyjskie posuwały się naprzód. Minęły już Gori, więc było dla nas jasne, że są zdeterminowane, by przedostać się również do stolicy. Przygotowywaliśmy się do wojny partyzanckiej. Wskutek militarnych działań Rosji kraj podzielony został na dwie części. Największa autostrada łącząca zachodnią i wschodnią Gruzję została odcięta. Udało nam się utrzymać do momentu rozpoczęcia negocjacji. Osiągnięte porozumienie nie było idealne - stanowiło proste i doraźne zawieszenie broni, a nie trwałe rozwiązanie pokojowe. Pierwotnie znalazły się w nim dwa niebezpieczne dla nas elementy włączone przez Rosję. Dotyczyły kwestii regionów i miały stanowić otwarcie negocjacji nad ich statusem. Zgodnie z naszym dotychczasowym stanowiskiem nie godziliśmy się na te zapisy, dlatego francuska delegacja musiała negocjować z Rosjanami ich usunięcie, co ostatecznie się udało.

\section{Jak ocenia Pani to porozumienie?}

Rzeczona umowa nie pozwalała na rozwiązanie konfliktu, ponieważ wymagałoby to znacznie szerszych działań. To, z czym mamy do czynienia obecnie, to porozumienie o zawieszeniu broni, które wciąż nie jest przestrzegane. Wojna nie wchodzi w aktywną fazę, ale nie stworzono też podstaw do rozwiązania konfliktu, m.in. poprzez wycofanie rosyjskich wojsk, co zakłada ten dokument. Rosja uznała niepodległość obu regionów, aby mieć pretekst do de facto bezprawnej obecności wojskowej na ich obszarze. Umowa została więc zrealizowana tylko częściowo, ale nie jest to problem samego 
dokumentu, lecz tego, że Rosja nie poniosła za swoje działania żadnych konsekwencji. Dlaczego więc miałaby wdrażać porozumienie o zawieszeniu broni? Z taką sytuacją mamy do czynienia nadal. Winne są zatem nie umowy, ale raczej brak stojących za nimi zobowiązań politycznych i wizji, co się stanie, jeżeli nie zostaną wdrożone. To samo dotyczy Ukrainy i memorandum budapesztańskiego - dość jasno określono, że suwerenność terytorialna tego państwa powinna była być zagwarantowana, ale gdzie były narzędzia mające to zagwarantować? Nie było ich.

Na pewno spodziewała się Pani w tym wywiadzie pytania o Polskę i stosunki polsko-gruzińskie. Jak ważną rolę $w$ tych wydarzeniach odegrała Polska?

Polska była bardzo ważna jako jeden z silnych sprzymierzeńców Gruzji w UE i NATO. Nawet z punktu widzenia zdolności wojskowych i ich unowocześniania była dla nas bardzo istotnym partnerem. Oczywiście życzyliśmy sobie w tym zakresie więcej i szybciej, zwłaszcza jeśli chodzi o możliwości obrony przeciwlotniczej. Produkowane w Polsce MANPAD-y ${ }^{2}$ były dla nas bardzo ważne, ponieważ brakowało nam tego rodzaju zdolności, co zresztą później się uwidoczniło. W czasie wojny bardzo dobrze radziliśmy sobie $\mathrm{w}$ defensywie na lądzie, ale byliśmy prawie bezbronni wobec ataków lotniczych i właśnie to zadecydowało o szybkim postępie rosyjskiej ofensywy. Bombardowania z powietrza sprawiły, że niezwykle trudno było prowadzić operację obronną. Nasze wojska lądowe były nawet silniejsze i przygotowane do walki z Rosjanami. Wyciągnęli zresztą z tego wnioski i w pewnym stopniu zmodernizowali później swoje siły lądowe. Byli zszokowani, że okazały się słabsze od młodych, inaczej wyszkolonych, przygotowanych i zaangażowanych w obronę własnego kraju sił gruzińskich.

\section{Powróćmy do Polski...}

Odczuwaliśmy wsparcie nie tylko ze strony polityków różnych opcji, ale także ze strony polskiego społeczeństwa, które w wielkiej części nam sprzyjało. Bardzo wzmacniało to nasze morale i nadzieje, że w przyszłości możemy skutecznie zabiegać o członkostwo w NATO i UE. Mogę stwierdzić, że Polska wyraziła silne poparcie i strategiczną wizję wobec prozachodniej

2 MANPAD (man-portable air-defence system) - przenośny przeciwlotniczy zestaw rakietowy. 
orientacji Gruzji i znaczenia naszego członkostwa w NATO, a także odwagę i zdolność do wspierania go nawet wówczas, gdy była za to wsparcie krytykowana. To pokazuje strategiczną wizję i siłę lidera. Tak było to zawsze postrzegane w Gruzji, jeśli chodzi o prezydenta Lecha Kaczyńskiego i cały jego zespół, rząd oraz inne siły polityczne. Zawsze podkreślamy to ponadpartyjne zainteresowanie i wsparcie, tak odmienne na przykład od postawy USA, gdzie zdarzało się, że jedna partia postrzegała nas jako zwolenników innej. W naszych sercach jest jednak miejsce nie dla partyjniactwa, ale dla strategicznych relacji między państwami.

Proszę pozwolić, że zapytam o epizod, który przeszedł do legendy, a nawet stał się czymś w rodzaju mitotwórczego czynnika relacji polsko-gruzińskich, a mianowicie misję prezydenta Kaczyńskiego. Czy uważa Pani, że miała ona strategiczny charakter lub jakikolwiek strategiczny wpływ na sytuację $w$ terenie? A może raczej jej znaczenie było symboliczne? Jak Pani to interpretuje i ocenia?

Muszę bardzo mocno podkreślić, że wizyta przywódców pięciu państw pod przewodnictwem prezydenta Kaczyńskiego uratowała naszą stolicę przed fizycznym atakiem wojsk rosyjskich. Wizyta prezydentów w Tbilisi zapowiedziana została dzień przed tym, jak dowiedzieliśmy się, że Sarkozy przyleci z Moskwy do Gruzji. Byli oni gotowi na poświęcenie i przyjazd do miasta mającego się stać celem ataku. Całkowicie rozumieliśmy wówczas powagę chwili i to, że Rosjanie zamierzają wkroczyć do naszej stolicy, więc przygotowywaliśmy się do działań wojennych w mieście. Gdy tylko pojawiła się informacja, że pięciu europejskich prezydentów fizycznie zjawi się w Tbilisi, wiedzieliśmy, że przynajmniej tego dnia Rosjanie nie zbombardują miasta i nie przypuszczą na nie szturmu. Dało nam to cenny czas. Kiedy prezydenci brali udział w publicznej demonstracji przed parlamentem, my siedzieliśmy wewnątrz, negocjując z Sarkozym i jego zespołem porozumienie o zawieszeniu broni. Zaangażowanie prezydenta Kaczyńskiego w sprawę Gruzji było niezmiernie ważne pod kątem strategicznym i inspirowało innych przywódców, by zrobili to samo. Nie trzeba niczego więcej dodawać - to oczywiste.

A jak interpretuje Pani przemówienie polskiego prezydenta? Wydawało się bardzo spontaniczne. Padły w nim mocne słowa o rosyjskim imperializmie i państwach mogących paść jego ofiarą. Czy myśli Pani, że stała za tym głębsza refleksja strategiczna? 
Jako Gruzinka mogę powiedzieć, że ilekroć wypowiadam słowa rosyjski imperializm, nie ma $\mathrm{w}$ tym nic spontanicznego. To wynik życiowego doświadczenia, funkcjonowania vis-à-vis Rosji i generacyjnego doświadczenia mojego kraju. Więc ilekroć jakiś Gruzin (a sądzę, że również Polak), polityk lub nie, powie coś o rosyjskim imperializmie, nie ma $w$ tym nic spontanicznego ani osobistego. To budowane przez pokolenia doświadczenie w kontaktach z Rosją. Kiedy zatem mówimy coś takiego, to jest to strategiczne, głęboko zakorzenione i przemyślane.

Jak zareagowała Pani na słynny reset Baracka Obamy w stosunkach z Rosją, mając w pamięci wydarzenia z 2008 r??

Ze strachem, nie $\mathrm{z}$ nadzieją...

Tłumaczę to sobie szerszym kontekstem geopolitycznym, w którym najważniejszym punktem odniesienia dla USA stała się rosnąca potęga Chin.

Rozumiem, ale jeśli skupiamy się na Europie, to zagrożenie ze strony Rosji lub jego brak jest czynnikiem kluczowym dla całego kontynentu. Nie można tutaj bagatelizować Moskwy i traktować jako aktora drugoplanowego. Kiedy resetuje się relacje, to trzeba konkretnie określić, kiedy będą rozdawane marchewki, a kiedy używane kije. Gdy ktoś podejmuje pozytywne działania, przekłada się to na całościowy pozytywny rozwój. Ale jeśli ktoś naraża ten rozwój na szwank i destabilizuje te pozytywne zmiany, to jakie mają być tego konsekwencje? Problem resetu polegał więc na tym, że niemal w całości zakładał gotowość Rosji do zbudowania bardziej stabilnych i konstruktywnych relacji z Zachodem, z pominięciem deklarowanej polityki i działań Moskwy, które powinny były skłonić do przygotowania planu B celem powstrzymania jej rewizjonizmu. Rosja to zrozumiała i wykorzystała na swoją korzyść. Mam jednak nadzieję, że w perspektywie historycznej okaże się to jedynie krótkoterminowym zyskiem, a na dłuższą metę państwo to straci w wymiarze strategicznym i nie będzie w stanie podzielić i osłabić zjednoczonej i wolnej Europy z Gruzją, Ukrainą, Mołdawią i Białorusią jako jej częściami. 